\title{
ENTREPRENEURIAL INTENTION AMONG POLYTECHNIC STUDENTS IN NIGERIA: THE ROLE OF SELF- EFFICACY AND SOCIAL NETWORKS
}

\author{
Kehinde A. Ojewumi \\ Department of Psychology, Obafemi Awolowo University, \\ Ile- Ife, Osun state Nigeria. \\ ojewumikehinde@gmail.com \\ Damilare A. Fagbenro \\ Department of Psychology, Obafemi Awolowo University, \\ Ile- Ife, Osun state Nigeria. \\ dareinui2008@yahoo.com
}

\begin{abstract}
This study was carried out to examine the role of self-efficacy and social networks on entrepreneurial intention among polytechnic students in Ile - Ife Osun state, Nigeria. Theory of Reasoned action was used as a theoretical framework for this study. A survey design was adopted. The data for this study was collected in 2018 via a purposive sampling technique, where 240 students (81 females and 159 males) with age range of $21-35$ years $(M=23.61, S D=2.63)$ were selected from one polytechnic. Inferential statistics (t-test for independent measure) was used to test the hypotheses in this study. Result showed that there was significant difference between entrepreneurial intention of polytechnic students with low self-efficacy and high self-efficacy. There was significant difference between entrepreneurial intention of polytechnic students with low social network and high social network. Therefore, to improve entrepreneurial intention among polytechnic students, psychologists should organize psycho-educational interventions aim at increasing self-efficacy and social networks of polytechnic students.
\end{abstract}

KEYWORDS: Entrepreneurial intentions, self-efficacy, social networking, polytechnic students

JEL CLASSIFICATION: L10, L13 L14

DOI: $10.2478 /$ IJEK-2019-0002

Received: November $26^{\text {th }}, 2018$

1st Revision: December $12^{\text {th }}, 2018$

Accepted: May 1', 2019

Reference: Ojewumi, K.A., Fagbenro, D.A. (2019). Entrepreneurial intention among polytechnic students in Nigeria: the role of self- efficacy and social networks. International Journal of Entrepreneurial Knowledge, 7(1), 20-30. doi: 10.2478/ijek-20190002

\section{INTRODUCTION}

Few decades ago, research on entrepreneurial activities has attracted attention by researchers from various fields such as psychology, sociology, and business administration. This is because of the important entrepreneurship has on the growth and development of any nation (Muhammad, 2012; Vivarelli, 2012; Kaegon \& Nwogu, 2012). In any developing economy, the role of entrepreneurial activities in achieving sustainable economic growth and development cannot be over-emphasized. Entrepreneurship promotes rapid economic growth and also minimizes the rate of unemployment in any country. Entrepreneurship can be said to be any effort at producing new business such as selfemployment, creating new business or the extension of existing business by an individual, or group of people (Reynolds, Camp, Bygrave, Autio, \& Hay, 2001). Entrepreneurship is as a result of complex balancing of prospect initiatives, risks and rewards. It can be viewed as a process by which individuals 
look for opportunities, enjoyable needs and wants through innovations, without regard to the resources they currently control. Through the practice of entrepreneurship, it is possible to maintain the scope of capital formation, job establishment and aid industrialization in a country (Asaju, Arome \& Anyio, 2014). On the other hand, an entrepreneur is a person who hunts for change, responds to it and exploits it as an opportunity.

In every society, entrepreneur is known to be a business front-runner and not just owner of capital. Such person is often driven with telescopic faculty, energy and ability that see business prospects and immediately explore them for opportunity (Ojewumi, Oyeleke, Agberotimi \& Adedayo 2018). An individual who wish to venture into entrepreneurship often begins with planned thought, desires and ideas which is often referred to as entrepreneurial intention in the literature. According to Abubakar, Salwa and Amina (2014) Entrepreneurial intention refer to individual willingness to start a new business. On the other hand Entrepreneurial intention is also described as the readiness of an individual to perform entrepreneurial behaviour, to engage in entrepreneurial action, to be selfemployed, or to establish new business (Dohse \&Walter, 2010). Furthermore, entrepreneurial intention is a reliable measure of entrepreneurial behaviour and entrepreneurial activity (Krueger, 2000). Generally, entrepreneurial intentions are a state of mind which directs and guides the actions of the individual towards the development and implementation of new business concepts (Bird, 1988). An individual may have potential to be an entrepreneur but may not make any transition into entrepreneurship unless they have such intentions (Mohammad, 2009).

Over the year, the level of unemployment in Nigeria is on an alarming rate despite different programmes set by government of Nigeria (NBC, 2016). Many polytechnic students despite having practical knowledge in their course of study always have the perception of getting a white collar job after graduation which on reality the job opportunities are not readily available. It therefore becomes pertinent to inculcate entrepreneurial intention among polytechnic students in order to reduce the menace of unemployment and improve wellbeing among intending graduates especially in a developing country like Nigeria. Many available studies have investigated many factors that could make individual have the intention of starting up his or her business such as personality traits (Akanbi, 2013; Owoseni, 2014), Values, attitudes and beliefs (Gasse \& Tremblay, 2011), entrepreneurial educational support and informal network (Amos, Oluseye \& Bosede 2015), fear of failure and entrepreneurial self-efficacy (Okoye 2016) creativity and age (Agbim, Oriarewo \& Owocho 2013), demographic variables such as gender, and age (Deh, assume \& Agyemang, 2013) and student level of studies (Bhandari, 2013). Although, these studies contribution are significant to entrepreneurial literature, however, to our knowledge no study have jointly investigated the influence of self-efficacy and social networks on entrepreneurial intention especially among less explored sample of polytechnic students in Nigeria. This represents a research gap in the literature which this present study hopes to fill.

\section{THEORETICAL BASES}

This section basically has three sub division where section one examine the concept of self-efficacy and social networks in relation to entrepreneurial intention. The second section also explores the theory of reasoned action as a theoretical framework. Lastly, the study explored past empirical studies that have been done on self-efficacy and entrepreneurial intention and social networks with entrepreneurial intention.

The concept of self-efficacy and its impact on entrepreneurial intention has been well documented in the literature (Chen, Greene, \& Crick, 1998; Lee Wong \& Foo, 2005). Self-efficacy is defined as an individual perception about their capabilities to create designated levels of performance that exercise influence over events that affect their lives (Bandura, 1986, 1997). Self-efficacy determines how people feel, think, and behave. Such beliefs yield this diverse effect through four major processes. A strong sense of efficacy produces human accomplishment and personal well-being in many ways. Bandura (1997) noted that people with high assurance in their capabilities approach difficult tasks as challenges 
to be mastered rather than as threats to be avoided. According to Lee et.al (2005), self-efficacious individuals are likely to perceive entrepreneurial environment positively and make the best out of the situation. In other words, high self-efficacy individuals are likely to exercise control over entrepreneurial events, while an individual low on self-efficacy may not be willing to exert extra effort in the face of obstacles and setbacks (Fu 2011).

Literature have showed that social networks have become essential for entrepreneurship and have also become a major paradigm for the mobilization of resources and the building of trust that is needed in business (Klyver \& Schott 2011; Hmieleski \& Corbett, 2006; Ripolles \& Blesa, 2005; Davidsson \& Honig, 2003). According to Ogunnaike and Kehinde (2013), social networks are nodes of individuals, groups, organizations, and related systems that tie on one or more types of interdependence: these include shared values, visions and ideas, social contacts, kinship, conflict, financial exchanges, trade, joint membership in organizations and group participation in events, among numerous other aspects of human relationship. Social networks help entrepreneurs to acquire the human, financial and social capital they need to achieve their goals (Welter \& Kautonen, 2005). This is because social networks can be used to gain access to valuable resources including advice, credibility/reputation, funding, information, knowledge/skills, social legitimacy, or social support (Klyver, 2005). Entrepreneurs' social networks connections may include advisors, business partners, buyers, customers, employees, friends/relatives, investors, mentors, shareholders, and suppliers (Klyver, 2007), with social networking activity differing according to the entrepreneur's particular needs and/or strategies (Ostgaard \& Birley, 1994). Social networking create avenue for acquiring new information concerning innovations and new trends in entrepreneurship. As a result of technological development, people are now making use of social media sites in advertising, giving information, sharing ideas etc. All these activities in one way or another could promote entrepreneurial intention among polytechnic students. It is from this foregoing that this paper examines the influence of self-efficacy and social networks on entrepreneurial intention among polytechnic students.

The theory of reasoned action was propounded by Ajzen (1991). The theory emphasized on behaviour intentions rather than attitudes as the main causes of behaviours (Ajzen \& Fishbein, 2005). The author of the theory asserts that people think rightly and make systematic use of information and facts accessible to them. Often time individual look at the implications of their action before they are willingly to take part or not take part in a given behaviour (Ajzen \& Fishbein, 2005). According to the theory, the most vital predictor of a person's behaviour is a combination of intention toward performing the behaviour and subjective norm. If an individual think that the outcome from performing behaviour is positive, such persons will have a positive attitude towards performing that behaviour. The opposite can also be stated if the behaviour is thought to be negative. Subjective norm is seen as a combination of perceived expectations from relevant individuals or groups along with intentions to comply with these expectations. Theory of reasoned action works most successfully when subjected to behaviours that a person can control. Behaviour that are not fully under an individual control, even though such person may be highly driven by his or her own attitudes and subjective norm, could make such individuals not to perform the behaviour. This could be due to some intervening environmental conditions. Relating this theory to this study people who have higher selfefficacy and better social networks may have the intention of starting up their own personal business because this attributes (self-efficacy and social networking) could push them toward having the intention which invariably would make them engage in the behaviour of starting their own personal business. It therefore means that understanding the role that self-efficacy and social networks would have on entrepreneurial intention remain paramount in this study.

\section{EMPIRICAL REVIEW}

Tarus, Kemboi, Okemwa and Otiso (2016) examine some variables such as (education support, social network, innovativeness and self-efficacy) on entrepreneurial intention among 1,649 undergraduate 
business students. The result found that self-efficacy was positively associated with entrepreneurial intention. Ojiaku, Nkamnebe and Nwaizugbo (2018) examined entrepreneurial intention among 288 National Youth Service Corp members (NYSC) in Anambra State, Southeast Nigeria using one of the mooring variables (self-efficacy). The study found that mooring variable of self-efficacy significantly influence entrepreneurial intentions among the sampled respondents. Ojewumi, Oyeleke, Agberotimi and Adedayo (2018) examine the influence of self-efficacy on entrepreneurial intention among One hundred and forty (140) students. The results revealed that there is significant difference between respondents with high self-efficacy and those with low self-efficacy on entrepreneurial intention. Okoye (2016) investigated the role of psychosocial factors (entrepreneurial self-efficacy) on entrepreneurial intention among 210 Nigerian graduates. The study found that those respondents with high entrepreneurial self-efficacy have higher significant entrepreneurial intention than respondents with low entrepreneurial self-efficacy. Afsaneh and Zaidatol (2014) examine the relationship between entrepreneurial self-efficacy and entrepreneurial intention among 722 private and public Malaysian university students. The study revealed that student entrepreneurial self-efficacy has positive impact on the intention to own a business.

Kuehn (2013) found that high self-efficacy positively influences entrepreneurial intention among sampled respondents. Similarly Ali, Topping, and Tariq (2010) explored self-efficacy on entrepreneurial attributes among Islamic University of Bahawalpur students. The study found that self-efficacy influence entrepreneurial intentions among the sampled respondents. Olanrewaju (2013) investigated the relationship between self-efficacy and entrepreneurial intentions among some Nigerian adolescents. The study found a positive significant relationship between self-efficacy and entrepreneurial intentions among the sampled adolescents. Baum and Locke (2015) found that self-efficacy was determined to have direct effect for venture growth among some selected adolescents. Carmen and Joaquín (2012) found that the higher the perceived self-efficacy of Latin adolescents the greater the entrepreneurial intention

In the study of Akanbi (2013) he found that self-efficacy linearly contributed to the prediction of entrepreneurial intention. Zhao (2015) found that self-efficacy was significantly related to career interests, career choice goals (intentions), and occupational performance. However, Lent (2012) also found that self-efficacy is the sole mediator between a person's abilities and his or her career interests. Self-efficacy may be used to predict the intended career-related intentions and behavior of individuals. It has been established that self-efficacy is the major influence on career-related behavior in Bandura's social cognitive theory. Despite the above-cited empirical researches, no study has investigated the influence of self-efficacy on entrepreneurial intention using data from polytechnic students; therefore, this study aims to overcome the limitation of earlier studies. Hence, we expect that:

Hypothesis one: The self-efficacy of the students is positively associated with their entrepreneurial intention.

Okafor and Ameh (2017) examined social networks and entrepreneurship orientation among 94 undergraduates. The findings revealed that a significant relationship exists between social networks density and proactiveness among student entrepreneurs in Nigerian universities. Felzensztein and Gimmon (2009) revealed that social networking is important in facilitating entrepreneurial orientation. Fairoz, Hibrobumi and Tanaka (2010) examine dimension of social network on entrepreneurial orientation among small and medium scale enterprises of Hambantota district in Sri Lanka. The study revealed a significant relationship between proactiveness, innovativeness, risk-taking on entrepreneurial orientation. Zafar, Yasin and Ijaz (2012) examined social networking on entrepreneurial intentions among entrepreneurs in Pakistan using survey design. The study revealed that social networking influence entrepreneurial intention. Klyver and Schott (2011) conducted a study on how social networks structure shapes entrepreneurial intention in Denmark. The study found that bridging social networks play an important role in shaping individuals' entrepreneurial intentions. 
Ameh and Udu (2016) explain the relationship between social networks size and risk disposition among student entrepreneurs. The findings revealed that a significant relationship was existing between social networks size and risk disposition among student entrepreneurs in Nigerian universities. Kacperczyk (2012) carried out a study on social influence and entrepreneurship. The study revealed that among individuals exposed to similar organizational influence, those exposed to entrepreneurial university peers are more likely to transit to entrepreneurship. Konrad (2013) conducted a study on cultural entrepreneurship. The study revealed that founders as well as managers can overcome numerous barriers through their engagement and activity in social networks, and thereby exercise to a significant degree a positive influence on establishing their enterprise. Felzensztein and Gimmon (2013) found that social networking is important in facilitating inter-firm cooperation in marketing activities and that informal meeting and weak ties are useful for sharing marketing information among managing directors. Jawahar and Nigama (2011) revealed that the structural dimension of social capital is the most important in influencing knowledge acquisition behaviour of opportunity recognition. Based on the pattern of relationships reported between social network and entrepreneurial orientation in the literature we expect that:

Hypothesis two: The social networks of the students is positively associated with their entrepreneurial intention

\section{AIM AND METHODOLOGICAL BASES}

Survey design was used to collect data which involve the use of questionnaire from a sample of population within a short period of time. The independent variables in the study are self-efficacy and social network while the dependent variable is entrepreneurial intention. The population of the study was polytechnic students in Ile - Ife Osun state, Nigeria. The reason why this population was used is because this set of individuals has polytechnic education characterized with practical orientated skills which could transform them to a potential entrepreneur. Purposive sampling technique was used to select two hundred and forty respondents (240) from the population of final year polytechnic students. The sample represents the population of the study because the researcher already knows the characteristic of this population to be polytechnic students and not university students. Therefore the sample for this study is 240 . Questionnaires were used to gather data from the participants in the study after the required permissions was obtained from the polytechnic management. Ethical issues of assurances were given on the bases of confidentiality and discretion of the study. The participants were informed of the purposes and/or objectives of the study. Direction on how to complete the questionnaires was also given by the researcher. The researcher assured the respondents that they can withdraw from the study at any time they so wish to do so. Questionnaires were disseminated to the respondents after their lecture free time at different departments visited by the researchers. A total of two hundred and fifty copies of questionnaires were distributed to the participants, but only two hundred and forty were retrieved as ten questionnaires were either badly filled and/or missing. The distribution of the questionnaires lasted for one week. The collected data was first coded and analysed using the IBM-SPSS version 22 software application. t-test for independent measures was used to test the two hypotheses postulated in the study. A structured questionnaire was used to collect data in this study. The questionnaire consists of one self-developed section and three standardised psychological scales. The first section comprises items that seek information on respondents' socio-demographic variables which include age, gender, religion and ethnicity. The validated scales consist of entrepreneurial intention, social-network scale and self-efficacy. Entrepreneurial intention was measured using the 15-item Entrepreneurial Intention Questionnaire developed by Lee, Lim, Lim, Ng, and Wong (2012). Some sample on the scale reads" I'd rather be my own boss than have a secure job" and "A career as entrepreneur is attractive for me". 5-Likert scale was used for scoring the scale which ranges from $5=$ strongly agree, to $1=$ strongly disagree. The scale has been used both locally and internationally, for instance Zeng, Liu, Zheng and Cao (2017) obtained a reliability coefficient of 0.89 while Ayedun, and Ajayi (2018) also reported a Cronbach Alpha coefficients ranging from 0.78 to 0.89 . 
The author reports co-efficient reliability of 0.87 . In this study a Cronbach alpha of 0.93 was reported Social network was measured using the 15 item social network scale developed by the researchers. The items were validated using the content and expert validity before the final items were used for collecting data. 5-point likert scale formats ranging from 1-strongly agree, 2-agrees, 3-undecided, 4-disagree, 5strongly disagree was used for scoring on the scale. A confirmatory factor analysis on the 15 items showed that all items loaded significantly on their constructs $(\mathrm{p}<.001)$, with weights ranging from 0.51 to 0.83 . The reliability analysis of social networking scale produced a Cronbach alpha of 0.85 .

Self-esteem was measured using the 10 item self-esteem scale developed by Rosenberg, (1965). Sample of the item reads "I feel that I'm a person of worth, at least on an equal plane with others" and "I wish I could have more respect for myself ". All items were answered using a 4-point Likert scale format ranging from strongly agree to strongly disagree. The author reports a reliability coefficient of 0.72 . Items 2, 5, 6, 8, and 9 are reverse scored. Higher scores on the scale indicate higher self-esteem, while lower scores indicate lower self-esteem. For the present study, a Cronbach alpha of 0.81 was established.

\section{RESULTS AND DISCUSSION}

The study examined the influence of self-efficacy and social network on entrepreneurial Intention among polytechnic students in Ile-Ife Osun state Nigeria. Two hypotheses were tested in this paper. The first hypothesis revealed that there was significant influence of self-efficacy on entrepreneurial intention meaning that polytechnic students who have high self-efficacy have higher entrepreneurial intention than polytechnic student with low self-efficacy.

Table 1 Summary table of independent sample t-test showing the influence of self-efficacy on entrepreneurial intention

\begin{tabular}{llllllll}
\hline & $\begin{array}{l}\text { Self- } \\
\text { efficacy }\end{array}$ & N & Mean & Std & df & t-value & Sig \\
\hline Entrepreneurial intention & Low & 94 & 37.29 & 7.64 & & & \\
& High & 146 & 45.23 & 7.75 & & -7.82 & $<.01$ \\
\hline
\end{tabular}

(Source: own)

Table 1 showed that self-efficacy have significant influence on entrepreneurial Intention, $\mathrm{t}(238)=$ 7.82; $\mathrm{p}<.01$. The result showed that polytechnic students with high self-efficacy $($ Mean $=45.23 ; \mathrm{SD}=$ 7.75) have higher entrepreneurial Intention than polytechnic students with low self-efficacy (Mean $=37.29 ; \mathrm{SD}=7.64)$. The hypothesis was accepted in this study.

The second hypothesis revealed that there was significant influence of social network on entrepreneurial intention meaning that polytechnic students who have high social network have higher entrepreneurial intention than polytechnic student with low social network

Table 2 Summary table of independent sample t-test showing the significance influence of social networks on entrepreneurial intention

\begin{tabular}{llllllll}
\hline $\begin{array}{l}\text { Social } \\
\text { networks }\end{array}$ & N & Mean & Std & df & t-value & Sig \\
\hline Low & 111 & 36.46 & 7.18 & & & \\
\hline
\end{tabular}


Table 2 showed that social network have significant influence on entrepreneurial Intention, $\mathrm{t}(238)=$ 11.81, $\mathrm{p}<.01$. The result showed that polytechnic students with high social network (Mean $=46.99$; SD $=6.54$ ) have higher entrepreneurial Intention than polytechnic students with low social network (Mean $=36.46 ; \mathrm{SD}=7.18)$. The hypothesis was also accepted.

The study examined the influence of self-efficacy and social network on entrepreneurial Intention among polytechnic students in Ile-Ife Osun state Nigeria. Two hypotheses were tested in this paper. The first hypothesis revealed that there was significant influence of self-efficacy on entrepreneurial intention meaning that polytechnic students who have high self-efficacy have higher entrepreneurial intention than polytechnic student with low self-efficacy. This finding was in line with Ojewumi, Oyeleke, Agberotimi and Adedayo (2018) where their study found that there is significant difference between respondents with high self-efficacy and those with low self-efficacy on entrepreneurial intention. This finding was also in line with Okoye (2016) who found that those respondents with high entrepreneurial self-efficacy have higher significant entrepreneurial intention than respondents with low entrepreneurial self-efficacy. Lent (2012) found that self-efficacy was significantly related to career interests, career choice goals (intentions), and occupational performance. However, Lent (2012) also found that self-efficacy is the sole mediator between a person's abilities and his or her career interests. Self-efficacy may be used to predict the intended career-related intentions and behavior of individuals. It has been established that self-efficacy is the major influence on career-related behavior in Bandura's social cognitive theory. in the study of Zhao's (2015) he provided evidence that individuals choose to become entrepreneurs because they are high in entrepreneurial self-efficacy - the belief that they can succeed in this role. The possible explanation for this finding may be unconnected with the fact that individual who believe in their strength and capacity, always believe they will be successful in having their own business, they are often prone to take on business despite the risk involved in starting or doing a business. The high efficacy could make them have the intention of starting up a business even in the face of stiffer competition and frustration.

The second hypothesis revealed that there was significant influence of social networks on entrepreneurial intention among polytechnic students. This implies that polytechnic students who have high social networks have higher entrepreneurial Intention than polytechnic students who have low social networks. The finding was also in accordance with study done by Zafar, Yasin and Ijaz (2012) who examined social networking on entrepreneurial intentions among entrepreneurs in Pakistan using survey design. The study revealed that social networking has significant influence on entrepreneurial intention. The finding was also in accordance with Fairoz, Hibrobumi and Tanaka (2010) who examine dimension of social network on entrepreneurial orientation among small and medium scale enterprises of Hambantota district in Sri Lanka. The study revealed a significant relationship between proactiveness, innovativeness, risk-taking on entrepreneurial orientation. Also the study of Okafor, and Ameh (2017) found that there was significant relationship between social networks and Entrepreneurship Orientation among Nigerian undergraduates. The study of Klyver and Schott (2011) found that only bridging social networks represented by low dense network, business size and entrepreneurial network play an important role in shaping individuals' entrepreneurial intentions. The study was also in line with Kacperczyk (2012) who revealed that among individuals exposed to similar organizational influence, those exposed to entrepreneurial university peers are more likely to transit to entrepreneurship. The study was also in accordance with Konrad (2013) who revealed that entrepreneur can overcome numerous barriers through their engagement and activity in social networks, and thereby exercise to a significant degree a positive influence on establishing their enterprise. The justification for this finding maybe unconnected with the fact that individual who want 
to owes personal business in Nigeria, must be able to first network in various ways either from friends, family or clients, this will give opportunity for experience, diversity of information, risk management as well as access and promotion of synergy.

\section{CONCLUSION}

It can be seen from our study that entrepreneurship can be enhanced through entrepreneurial intention which invariably could go a long way to reduce the problem of unemployment and improve the standard and wellbeing of students and youths especially students with polytechnic education. From the findings of this study, it was concluded that self-efficacy and social network have influence on entrepreneurial intention among polytechnic students. Based on these conclusions, the study recommended that psychologists should organize psycho-educational interventions aim at increasing self-efficacy and social networking of polytechnic students. It also recommended that policy maker such as government should introduce meaningful entrepreneur education into the polytechnic curriculum such that it will enhance students to have the intention of wanting to venture into entrepreneur business. Theoretically, findings of this study lend support to and extend the theory of reasoned action such that individuals who have higher self-efficacy and better social networking may have the intention of starting up their own personal business. Despite the significant contribution of this study to literature, it still has some limitations. Firstly, the study was conducted using just one polytechnic in southwest Nigeria, this thereby limit the generalization of the result to other polytechnics in Nigeria and outside Nigeria. Secondly, the issue of data collection which was based on self-report gave room for participant's bias response to the questions. Thirdly, the method of data collection and statistical analysis used for this study was inferential statistic ( $\mathrm{t}$-test for independent measure) which was also a major limitation. Lastly, time constraint was also a limitation in this study. Therefore, future studies should put the foregoing limitations into account when investigating factors that could predispose entrepreneurial intention among students.

\section{ACKNOWLEDGEMENTS}

The researchers acknowledge the participants used in this study. Also, Mr Bankole Olusiji Smith for the English editing and proofreading of the paper

\section{REFERENCES}

Abubakar S., Salwa K., \& Amina M. (2014). An assessment of students' entrepreneurial intention in tertiary institution: A case of Kano state polytechnic, Nigeria. International Journal Asian Social, 4(3), 434-443.

Afsaneh, F., \& Zaidatol, Y. (2014). Relationship between entrepreneurial self-efficacy and entrepreneurial intention among Malaysian university students. Academy of Entrepreneurship Journal, 6(1), 58-63.

Agbim, K. C., Oriarewo, G. O., \& Owocho, M. (2012).Factors influencing entrepreneurial intentions among graduates of Nigerian tertiary institutions. International Journal of Business and Management Invention, 2, 36-44.

Ajzen, I., \& Fishben, M. (2005). The influence of attitudes on behaviour. The Handbook of Attitudes, 173221.

Akanbi, S. T. (2013). Familial Factors, Personality Traits and Self-Efficacy as Determinants of Entrepreneurial Intention among Postgraduate Students in Nigerian Universities: Conceptual Review Intention among Vocational Based College Of Education Students in Oyo State, Nigeria. An unpublished P.hd Thesis from the department of education, University of Ibadan, Nigeria.

Ali, A., Topping, K.J., \& Tariq, H.R. (2010). Entrepreneurial attributes among postgraduate students of a Pakistani university, US-China. Education Review, 7(5), 66-77. 
Ameh, A., \& Udu, A. (2016). Social Networks and Entrepreneurship Orientation among Students in Nigerian Universities: A Study of Social Network Size and Risk Disposition. Business and Management Research, 5(2), 1-11.

Amos, A., Oluseye, O., \& Bosede, A.(2015).Influence of Contextual Factors on Entrepreneurial Intention of University Students: The Nigerian Experience. Journal of South African Business Research, 2- 10. https://doi.org/10.5171/2015.750622

Asaju, K., Arome, S., \& Anyio, S. (2014). The rising rate of unemployment in Nigeria the socioeconomic and political implications. Global Business and Economic Research Journal, 3(2), 12-32.

Ayedun, T., \& Ajayi, M.(2018).Entrepreneurial Intention among Students of Selected Tertiary Institutions in Ondo State. International Journal of Development Strategies in Humanities, Management and Social Sciences 8,(1) 1-16

Bandura, A. (1986). The explanatory and predictive scope of self-efficacy theory. Journal of Clinical and Social Psychology, 4, 359-373.

Bandura, A. (1997). Self-efficacy: The exercise of control. New York: Freeman.

Baum, J. R.., \& Locke, E. A. (2015). The relationship of entrepreneurial traits, skill, and motivation to subsequent venture growth. Journal of Applied Psychology, 89, 587- 598.

Bhandari, N. C. (2012). Relationship between students' gender, their own employment, their parents' employment, and the students' intention for entrepreneurship. Journal of Entrepreneurship Education, 15, 133-144.

Bird, B. J. (1988). Implementing entrepreneurial ideas: The case of intention. Academy of Management Review, 13 (3), 442-453.

Carmen, A., \& Joaquín G. (2012).Entrepreneurial intention models as applied to Latin America", Journal of Organizational Change Management, 25 (5), 721 - 735

Chen, CC., Greene, PG., \& Crick, A. (1998). Does entrepreneurial self-efficacy distinguish entrepreneurs from managers? Journal of Small Business Venturing, 13(4), 295-316.

Deh, I. Y., Asuamah, S. Y., \& Agyemang, I. K. (2013). The Link between Demographics and Perceive Barriers to Entrepreneurship. Journal of Small Business and Entrepreneurship Development, 1(1), 42-50.

Dohse, D., \& Walter, S. G. (2010). The role of entrepreneurship education and regional context in forming entrepreneurial intentions: Document de treball de l'IEB. ent.ut.ac.ir/jger/images/usersfiles/1/file/pdf/kim\%20kliver\%201.pdf.

Fairoz, F.M., Hirobumi, T., \& Tanaka, Y. (2010). Entrepreneurial Orientation and Business Performance of Small and Medium Scale Enterprises of Hambantota Distinct, Sri Lanka. Asian Social Science 6 (3), 34-46. URL: http://www.mgt.ruh.ac.ik/staff-index.php?page=5 user=mafasiya

Felzensztein C., \& Gimmon, E. (2013). Social Network and Marketing Cooperation in Entrepreneurial Clusters: An International Comparative Study. Journal of International Entrepreneurship, 4, 01- 11. D0I: 1007/510843-009-0041-2

Fu, J. (2011). Understanding career commitment of IT professionals: Perspectives of push-pullmooring framework and investment model. International Journal of Information Management, 31, 279-293. https://doi.org/10.1016/j. ijinfomgt.2010.08.008

Gasse, Y., \& Tremblay, M. (2011). Entrepreneurial beliefs and intentions: A cross-cultural study of university students in seven countries. International Journal of Business, 16(4), 303.

Hmieleski, O., \& Corbett, (2006). Influence of Social Capital on Entrepreneurial Opportunity Recognition Behaviour. International Journal of Economics and Management, 5(1), 351-368. Retrieved from: http:// econ.upm.edu.my/ijem/vol5 no2/bab10.pdf.

Jawahar, D.P., \& Nigama K. (2011). Influence of Social Capital on Entrepreneurial Opportunity Recognition Behaviour. International Journal of Economics and Management, 5(1), pp351-368.URL: http://econ.upm.edu.my/ijem/vol5no2/bab10.pdf

Kacperezyk J.A (2012). Social Influence and Entrepreneurship; The Effect of University Peers on Entrepreneurial Entry. Organization Science Articles in Advance, 13, 1-20.

Kaegon L. E., \& Nwogu U. J. (2012). Entrepreneurship Education in Nigerian Universities: A Panacea for Unemployment in Nigeria: British Journal of Advance Academic Research, 1 (1), 57-67. 
Klyver, K. \& Schott, T. (2011). How Social Network Structure Shapes Entrepreneurial Intentions. Journal of Global Entrepreneurship Research, 1(1), 03-19.

Klyver, K. (2006). Action Focus: Using social networks - a guide for entrepreneurs. Australian Graduate School of Entrepreneurship Research Report Series, 3, no. 7. Melbourne: Swinburne University of Technology.

Klyver, K.. (2007). Entrepreneurs' social networks - encouragement or criticism paper presented at 24th Babson Kaufman Entrepreneurship Research Conference, Glasgow, 2-5 June 2004

Konrad, P. (2013).Networking Strategies for Entrepreneurs. International Opportunity Recognition Among Small and Medium Sized Family Firms. Journal of Small Business Management, 49(3), 490514.

Krueger, N. F. (2000). The cognitive infrastructure of opportunity emergence. Entrepreneurship: Theory and Practice, 3, 5-23.

Kuehn, K. (2013). Entrepreneurial intentions research: Implications for entrepreneurship education. Journal of Entrepreneurship Education, 11, 87-98.

Lee, D., \& Tsang, E. (2001).The effects of entrepreneurial personality, background and network activities on venture growth. Journal of Management Studies, 38(4), 583 - 602.

Lee, L., Wong, P. K., \& Foo, M. D., (2005). Antecedents of entrepreneurial propensity: findings from Singapore, Hong-Kong, and Taiwan, MPRA paper No, 2615 retrieved online at http://mpra.ub.uni-muenchen.de/2615.

Lent, J. (2012).The Entrepreneurial Propensity of Women. Entrepreneurship Theory and Practice, 31, 341364.

Muhammad, D. A. (2012). Entrepreneurial Intention among Undergraduate Students In International Islamic University Malaysia-IIUM: A paper presented at the 6th Islamic Development Management Conference (IDMAC, 2012) Universiti of Sains Malaysia.

Muhammed, C. (2009). Impact of contextual factors on entrepreneurial intention in India, International Journal Eng Management Research, 3(6), 76-82

National Bureau of Statistics (2016). Bureau Report of the National Bureau Report.

Ogunnaike, O. O., \& Kehinde, O. J. (2013). Social Networking and Business Performance: The Case of Selected Entrepreneurs in Ota, Nigeria. Journal of Business Administration and Management Sciences Research, 2(5), 116-122. URL: http:/www.apexjournal.org/JBAMSR.

Ojewumi, A., Oyeleke, J., Agberotimi, F., \& Adedayo, O. (2018). The Influence of Gender and SelfEfficacy on Entrepreneurial Intentions among Obafemi Awolowo University Undergraduate Students. Africology: The Journal of Pan African Studies, 11 (2), 169-185.

Ojiaku, C., Nkamnebe, D., \& Nwaizugbo, C. (2018).Determinants of entrepreneurial intentions among young graduates: perspectives of push-pull-mooring model. Journal of Global Entrepreneurship Research, 12, 8-24.

Okafor, C., \& Ameh, A.(2017).Social Networks and Entrepreneurship Orientation among Students in Nigerian Universities: A Study of Social Network Density and Proactiveness. International Journal of Business and Management Invention, 6 (7), 33-41.

Okoye L. (2016). Psychosocial predictors of entrepreneurial intention among Nigerian graduates. International Journal of Psychology and Counselling, 8(6), 73-80.

Olanrewaju A.(2013).Demographics, Entrepreneurial Self-Efficacy and Locus of Control as Determinants of Adolescents' Entrepreneurial Intention in Ogun State, Nigeria. European Journal of Business and Social Sciences, 1 (12), 59-67.

Ostgaard, TA., \& Birley, S.(1994). Personal Networks and Firms' Competitive Strategy - A Strategic or Coincidental Match? Journal of Business Venturing, 9(4), 281-305.

Owoseni, O. O. (2014). The Influence of Some Personality Factors on Entrepreneurial Intentions .International Journal of Business and Social Science, 5(1), 278-284.

Reynolds, PD., Camp, SM., Bygrave, WD., Autio, E., \& Hay, M. (2001). Global Entrepreneurship Monitor 2001 Executive Report, Kauffman Centre for Entrepreneurial Leadership.

Ripolles, L., \& Blesa, R. (2005). The Role of Advice Sources for Entrepreneurship and Innovation. 35th DRUID Celebration Conference 2013, Barcelona, Spain, June 17-19. http://dx.doi.org/jelcodesM13033 
Rosenberg, M. (1965). Society and the adolescent self-image. Princeton, NJ: Princeton University Press. Shapero, A., \& Sokol, L. (1982). The social dimensions of entrepreneurship. Englewood Cliffs: Encyclopedia of Entrepreneurship.

Tarus, T., Kemboi, A., Okemwa, D., \& Otiso, K. (2016). Determinants of Entrepreneurial Intention: Selected Kenyan Universities Service Sector Perspective. International Journal of Small Business and Entrepreneurship Research, 4(6),1-52

Vivarelli, M.(2012). Drivers of Entrepreneurship and Post-Entry Performance: Microeconomic Evidence from Advanced and Developing Countries; World Bank Policy Research Working Paper WPS6245.

Welter, F., \& Kautonen, T. (2005). Trust, social networks and enterprise development: Exploring evidence from East and West Germany. International Entrepreneurship \& Management Journal, 1(3), 367-379.

Zafar, M.J., Yasin, G., \& Ijaz, M. (2012). Social Networking as a Source for Developing Entrepreneurial Intentions among Entrepreneurs; A Case of Multan. Asian Economic and Financial Review 2(8), 1072-1084. URL: http:/ /www.aessweb.com/pdf-files/1072-1084.pdf.

Zeng, F., Liu, Q., Zheng, M., \& Cao, X.(2017).Emotional Competences and Entrepreneurial Intentions: A Case Study of College Student Entrepreneurs. International Review of Social Sciences and Humanities, 13(1), 11-22

Zhao, F. (2015). Exploring the synergy between entrepreneurship and innovation. International Journal of Entrepreneurial Behavior and Research, 11 (1), 25-41. 